\title{
Accuracy of MR Imaging in Preoperative Staging of Rectal Cancer
}

\author{
Preoperatif Rektum Kanseri Evrelemesinde MR Görüntülemenin Doğruluğu
}

Didem Yasemin Sönmez'1 , Elif Peker'1, Saba Kiremitci², Ayșe Erden'1, Ayhan Kuzu³

epartment of Radiology, Ankara University, School of Medicine, Ankara, Turkey

Department of
Ankara, Turkey Department of $G$ Ankara, Turkey

Aim: In this study we aimed to evaluate the accuracy of preoperative rectal cancer staging in our center using 1.0 Tesla Magnetic resonance imaging (MRI) with phased-array coils and determine if the results can be improved by adopting thin-section MRI techniques.

Materal and Methods: Eighty-four patients with biopsy proven rectal cancer were prospectively evaluated by MRI using either the standard ( $8 \mathrm{~mm}$ sections in all planes) or the thin-section protocol (additional $5 \mathrm{~mm}$ sections in oblique axial plane perpendicular to the long axis of the tumor). Patients undergoing surgery with or without neoadjuvant therapy (standard MRI, $n=15$ and thin-section MRI, $n=22$ ) were included in the analysis. TNM stage, circumferential resection margin (CRM) and adjacent organ involvement were compared with histopathologic findings.

Results: In the thin-section group, estimation of tumor stage was $59 \%$ accurate, showing fair agreement with histopathology $(\kappa=0.38, p<0.05$ ); sensitivity and specificity rates were $100 \%$ and $59 \%$ for $\mathrm{T} 2$ and $47 \%$ and $100 \%$ for T3 stages. In the standard group estimation of T stage was only $40 \%$ accurate, showing no significant agreement with histopathology. The most frequent staging error was under-staging of borderline pT3 tumors in both groups. Accuracy, sensitivity and specificity of positive CRM were $67 \%, 67 \%$ and $95 \%$ for thin-section group and $50 \%, 100 \%$ and $93 \%$ for standard group, respectively; agreement with histopathology was significant only for the thin-section group $(\kappa=0.61 ; p<0.05)$. Accuracy of nodal status was $77 \%$ in the thin-section group $(\kappa=0.51 ; p<0.05)$ and $87 \%$ in the standard group $(\kappa=0.75 ; p<0.05)$.

Conclusion: Thin-section MRI techniques can be used to improve tumor staging and positive CRM predictions even with low field magnet systems.

Key Words: Magnetic Resonance Imaging, Rectal Cancer, Tumor Staging

Amaç: Bu çalısmada merkezimizde 1.0 Tesla Magnetik Rezonans (MR) cihazı ile faz dizilimli koil kullanarak preoperatif rektum kanseri evrelemesinin doğruluğunun değerlendirilmesi ve ince kesit MR teknikleri kullanarak sonuçların iyileștirilebilir olup olmadığının belirlenmesi amaçlanmıștır.

Gereç ve Yöntem: Biyopsi ile rektum kanseri tanısı kanıtlanmıș 84 hasta standart (tüm planlarda 8 mm kalınlığında kesitler) ya da ince kesit protokol (ek olarak tümörün uzun aksına dik $5 \mathrm{~mm}$ kalınlığında kesitler) kullanılarak Manyetik rezonans görüntüleme (MRG) ile prospektif olarak değerlendirilmisțir. Neoadjuvan tedavi alarak ya da almadan (standart MRG, $n=15$ ve ince kesit MRG, $n=22$ ) opere edilen hastalar analize dahil edilmiștir. TNM evrelemesi, çevresel rezeksiyon sınırı ve komșu organ tutulumu histopatolojik bulgular ile karșılaștırılmıștır.

Bulgular: Ince kesit grubunda, tümör evresi histopatoloji $(\kappa=0.38, p<0.05)$ ile \%59 uyumlu, hassasiyet ve özgüllük ise T2 evresi için \%100 ve \%59, T3 evresi için \%47 ve \%100 doğruluktadır. Standart grupta T evresi histopatoloji ile anlamlı bir uyum göstermemekle birlikte yalnızca \%40 doğruluktadır. İki grupta en sık evreleme hatası, sınırda pT3 tümörlerin düșük evrelenmesidir. Çevresel rezeksiyon sınırı pozitifliğinin doğruluk, duyarlılık ve özgüllüğü sırasıyla, ince kesit grubu için $\% 67, \% 67$ ve $\% 95$; standart grup için $\% 50, \% 100$ ve $\% 93$ tür. Bu sonuçlarda histopatoloji $(\kappa=0.61 ; p<0.05)$ yalnızca ince kesit grubu için anlamlıdır. Nodal evrelemenin doğruluğu ince kesitli grupta $\% 77(\kappa=0.51 ; p<0.05)$ ve standart grupta $\% 87(\kappa=0.75 ; p<0.05)$ dir.

Sonuç: İnce kesitli MRG teknikleri, düșük manyetik alan sistemlerde bile tümör evrelemesinin ve pozitif çevresel rezeksiyon sınırı tahminlerinin geliștirilmesi için kullanılabilir.

Anahtar Sözcükler: Manyetik Rezonans Görüntüleme, Rektum Kanseri, Tümör Evreleme

Rectal cancer, defined as a tumor localized within $15 \mathrm{~cm}$ from the anal verge, accounts for approximately one third of all colorectal cancers and presents with a high local recurrence rate. Total mesorectal excision (TME), where rectum is removed along with mesorectum and the surrounding mesorectal fascia, has increasingly replaced blunt pelvic dissection and improved local recurrence rates, by reducing the risk of tumor spillage (1). Additionally, in advanced cases surgery is supported by neoadjuvant or adjuvant therapies to prevent local recurrence as well as distant metastasis. Preoperative radiotherapy or chemoradiotherapy is preferred over postoperative chemoradiotherapy because its better tolerability and 
reduced local recurrence rates have been shown with preoperative treatment (2-4). Also, rectal cancer has a higher recurrence rate than colon cancer, because of extensive lymphatic drainage of the pelvis (5). Thus, rectal cancer management relies on accurate preoperative radiological imaging to determine the patients who would benefit from neoadjuvant therapies.

Although there are several imaging modalities each with its own advantages and disadvantages, magnetic resonance imaging (MRI) appears to provide the best soft-tissue contrast and can be used to predict prognostic factors such as tumor stage, nodal involvement and circumferential resection margin (CRM) involvement in rectal cancer. CRM has been proven to influence patient outcomes, and increasingly this feature is taken into consideration when determining treatment options (6). Accurate staging prevents undertreatment or overtreatment of rectal cancer (7). Usage of 1.5 Tesla magnets, phased-array pelvic coils, and high spatial resolution, thin-section MRI techniques, which can be summarized as the use of $3 \mathrm{~mm}$ oblique axial scans perpendicular to the long axis of the tumor, have increased the accuracy of predictions in preoperative rectal cancer staging $(8,9)$. In recent years, 3.0 Tesla MRI was also used in some centers to acquire images at even higher resolution, with variable success. Unfortunately, acquiring the latest technology is not always feasable due to economic constraints in most hospitals, especially in developing countries. In our institution, 1.0 Tesla phased-array MRI was used in preoperative assessment of patients with rectal cancer until 2 years ago. Our standard protocol involved $8 \mathrm{~mm}$ slice thickness with or without contrast enhancement. In this prospective study we aimed to evaluate the accuracy of our standard protocol in predicting prognostic factors such as transmural invasion, nodal status and CRM, and determine whether the accuracy of preoperative staging can be improved by adopting the thin-section MRI techniques.

\section{Methods}

This was a prospective study evaluating the accuracy of preoperative rectal cancer staging in our center using the available 1.0 Tesla MRI system with phasedarray multichannel coils. The standard MRI protocol used in our hospital was compared to an alternative thin-section MRI protocol, against the histopathological findings accepted as standard reference. Patients were informed about the study and oral consent was obtained.

\section{Patient selection}

Between November 2005 and June 2009, 84 patients with endoscopic biopsyproven rectum cancer were referred to our department for preoperative staging. The first set of 42 patients were examined using the standard MRI protocol and the second set of 42 patients were examined using the thinsection MRI protocol. Patients receiving neoadjuvant therapy $(n=34)$, patients deemed inoperable due to liver metastasis $(n=2)$, patients rejecting surgery $(n=1)$, and patients lost to follow-up after MRI $(\mathrm{n}=10)$ were excluded from the analysis. Patients receiving radiotherapy one month $(n=3)$ and 3 years $(n=1)$ prior to MRI (4 patients in total) were included. Thus, results from 15 patients with standard MRI and 22 patients with thin-section MRI were included in the analysis.

\section{MRI protocol}

Scans were performed on a 1.0 Tesla MRI unit (Signa Horizon; GE Medical Systems, Milwaukee, Wis). Patients were placed in the feet-first supine position with a phased-array coil wrapped around the pelvis. Initial localizing scans in all 3 planes were followed by sagittal T2-weighted fast spin-echo (FSE, TR/TE: 4100/102 ms, echo train length: 18 , band width: $41 \mathrm{kHz}$, field of view: $24 \mathrm{~cm}$, slice thickness/gap: 6/1 mm, number of excitation: 4, matrix: 320x192); coronal short tau inversion recovery (STIR, TR/TE: 5000/30 ms, TI:130, echo train length: 12, band width: $31 \mathrm{kHz}$ field of view: $26 \mathrm{~cm}$, slice thickness/gap: $7 / 1 \mathrm{~mm}$, number of excitation: 4, matrix: 256x192); axial STIR (TR/TE: 5000/30 ms, TI:130, echo train length: 8 , band width: 31 $\mathrm{kHz}$, field of view: $22 \mathrm{~cm}$, slice thickness/gap: 8/1 $\mathrm{mm}$, number of excitation: 2, matrix: 256x160); axial T1-weighted spin echo (SE, TR/TE: 430/14 ms, band width: $20 \mathrm{kHz}$, field of view: $22 \mathrm{~cm}$, slice thickness/gap: $8 / 1$ mm, number of excitation: 2 , matrix: 320x192) and axial T2-weighted FSE scans (TR/TE: 5000/102 ms, echo train length: 19, band width: $31 \mathrm{kHz}$, field of view: $22 \mathrm{~cm}$, slice thickness/gap: 8/1 $\mathrm{mm}$, number of excitation: 3, matrix: 320x192).

In the second half of the patients (the thinsection MRI group) an additional thinner oblique axial T2-weighted sequence (TR/TE: 3000/102 ms, echo train length: 18, band width: $41 \mathrm{kHz}$, field of view: $16 \mathrm{~cm}$, slice thickness/gap: 5/0.5 mm, number of excitation: 6, matrix: 320x192) was used to obtain images directly perpendicular to the long axis of the tumor. Thinsections were $5 \mathrm{~mm}$-thick, as this was the thinnest section we could use whilst preserving an optimal signal-to-noise ratio.

After obtaining T2-weighted sequences, all patients were administrated intravenous gadolinium-based contrast agent (0.2 $\mathrm{mL} / \mathrm{kg}$ ) and contrast-enhanced fat suppressed T1-weighted images were obtained in all three planes (axial spinecho, sagittal gradient echo and coronal gradient echo). Total scan time was 45 55 minutes.

Patients were examined following a minimum of 5-6 hours fasting to minimize possible complications related to intravenous contrast material use and prevent artifacts due to bowel peristaltism. No bowel cleansing, antiperistaltic medication or air insufflation was applied.

\section{MRI interpretation}

All images were assessed by a single radiologist (D.S.). Tumor localization, transmural invasion depth ( $\mathrm{T}$ stage), distance to mesorectal fascia 
(circumferential resection margin), mesorectal fascia involvement, presence of metastatic lymph nodes $(\mathrm{N}$ stage) and adjacent organ invasion were determined according to below criteria.

Tumor localization was categorized as distal if it was found within $5 \mathrm{~cm}$ of anorectal junction and proximalmidrectal if it was found between 5 to $15 \mathrm{~cm}$ from anorectal junction. Transmural invasion depth ( $\mathrm{T}$ stage) was determined by TNM criteria established for MRI, according to rectal wall layers visualized on T2-weighted images $(10,11)$. Thin spiculations into perirectal fat and interruptions in outer longitudinal muscle layer were not considered as tumoral invasion. Nodular areas continuous with mural component of the tumor obliterating hypointensity of the muscle layer were considered significant in terms of perirectal fat invasion (stage T3).

Distance to mesorectal fascia was measured from primary tumor or (if present) perirectal tumor deposit or metastatic mesorectal lymph node, whichever was closest. Circumferential resection margin was considered positive when this distance was $1 \mathrm{~mm}$ or less.

Mesorectal fascia involvement (stage T4) was considered when mesorectal fascia thickening and/or retraction was observed in the area facing the tumor. In tumors with extramural extension, adjacent organ involvement was considered when irregular tumoral signal intensity extended towards adjacent organ obliterating the fat signal.

Lymph node metastasis ( $\mathrm{N}$ stage) was determined using the cited criteria from Brown et al. (12). Lymph nodes with irregular border or mixed signal intensity were considered metastatic.

\section{Histology and Surgery}

Histopathological examination was conducted according to Quirke et al. (13), by a pathologist blinded to the MRI results. Twenty nine patients had sphincter sparing anterior resection or low anterior resection surgery. Seven patients had abdominoperineal resection. One patient with ulcerative colitis history underwent a total colectomy.

\section{Statistics}

Histopathological findings were accepted as gold standard. Agreement between MRI and histologic TNM stage and circumferential resection margin positivity were compared using $\kappa$ statistics. Sensitivity, specificity, positive predictive value, negative predictive value and diagnostic accuracy were calculated for both MRI protocols. A $p$ value of $<0.05$ was considered statistically significant.

\section{Results}

Data from 19 men and 18 women with a mean age of 57 years $(55.54 \pm 13.40$, range: 25-83) were included in the analysis. Tumor localization was proximal-mid rectum in $59.5 \%$ $(n=22)$, distal in $37.8 \%(n=14)$ and along the whole length of the rectum in $2.7 \%(n=1)$ of the patients. Histologic types of tumor were determined as adenocarcinoma in $78.4 \%(n=29)$, mucinous adenocarcinoma in $16.2 \%$ $(\mathrm{n}=6)$ and ringlet cell carcinoma in $5.4 \%(n=2)$. Thin-section MRI protocol (5 $\mathrm{mm}$ oblique axial T2weighted scans perpendicular to the tumor) was used in twenty-two patients while standard MRI protocol was used in 15 patients.

\section{T staging}

Table 1 presents $\mathrm{T}$ stage prediction by the thin-section and standard MRI protocols compared to the histopathologically established $\mathrm{T}$ stage. In the thin-section MRI group, accuracy of tumor stage prediction was $59 \%$ $(13 / 22)$, showing fair agreement with histopathology $(\kappa=0.38, p<0.05)$. For T2 stage, sensitivity was $100 \%(5 / 5)$, specificity $59 \%(10 / 17)$, positive predictive value (PPV) 42\% (5/12) and negative predictive value (NPV) $100 \%(10 / 10)$. For T3 stage, sensitivity was $47 \%$ (7/15), specificity $100 \%$ (7/7), PPV 100\% (7/7) and NPV $47 \% \quad(7 / 15)$ (Figure 1). Diagnostic performance of thin-section MRI could not be calculated for T1 and T4 stages, due to insufficient number of patients diagnosed at these stages.
Table 1. T stage prediction by MRI compared to histopathology in the thin-section $(n=22)$ and standard MRI $(n=15)$ groups.

\begin{tabular}{|c|c|c|c|c|c|}
\hline \multicolumn{6}{|c|}{$\begin{array}{c}\text { Thin-section MRI group }(\kappa=0.38, p<0.05) \\
\text { Histopathology }\end{array}$} \\
\hline MRI & pT0 & pT1 & pT2 & pT3 & pT4 \\
\hline T0 & 1 & 0 & 0 & 0 & 0 \\
\hline T1 & 0 & 0 & 0 & 0 & 0 \\
\hline T2 & 0 & 1 & 5 & 6 & 0 \\
\hline T3 & 0 & 0 & 0 & 7 & 0 \\
\hline T4 & 0 & 0 & 0 & 2 & 0 \\
\hline Total & 1 & 1 & 5 & 15 & 0 \\
\hline \multicolumn{6}{|c|}{$\begin{array}{r}\text { Standard MRI group ( } p>0.05) \\
\text { Histopathology }\end{array}$} \\
\hline MRI & pT0 & pT1 & pT2 & pT3 & pT4 \\
\hline T0 & 0 & 0 & 0 & 0 & 0 \\
\hline T1 & 0 & 0 & 0 & 0 & 0 \\
\hline T2 & 0 & 2 & 2 & 5 & 0 \\
\hline T3 & 0 & 0 & 1 & 3 & 0 \\
\hline T4 & 0 & 0 & 0 & 1 & 1 \\
\hline Total & 0 & 2 & 3 & 9 & 1 \\
\hline
\end{tabular}

In the thin-section MRI group, one pT1 tumor was over-staged as T2, two pT3 tumors were over-staged as T4, and six pT3 tumors were under-staged as T2 (Figure 2). Of the two patients overstaged as T4, one patient was diagnosed to have tumor invasion in the posterior wall of vagina by MRI. However, at histopathology only macroscopical adherence to posterior wall of vagina was observed with no microscopic evidence of tumoral invasion. Medical history of the patient revealed neoadjuvant therapy applied prior to the MRI scan. The second patient was observed to have peritoneal involvement on MRI, but not on histopathology and no apparent cause for this discrepancy could be established, possibly due to insufficient communication between the multidisciplinary team members. Of the understaged patients with pT3, two had tumors located high in the rectum and had focal infiltration into serosa, while the remaining four had tumors with minimal perirectal fat infiltration, which could not be detected by MRI.

In the standard MRI group, accuracy of tumor stage prediction was $40 \%(6 / 15)$ with no statistically significant agreement between MRI and histopathology $(p>0.05)$. For T2 stage, sensitivity was $66 \%(2 / 3)$, specificity $42 \%$ (5/12), PPV $22 \%(2 / 9)$, NPV $83 \%(5 / 6)$. For T3 stage, sensitivity was $33 \%(3 / 9)$, specificity $83 \%$ (5/6), PPV 75\% (3/4), NPV $\% 45$ (5/11). Diagnostic performance could not be calculated for T1 and T4 due to insufficient number of patients diagnosed at these stages. 
A

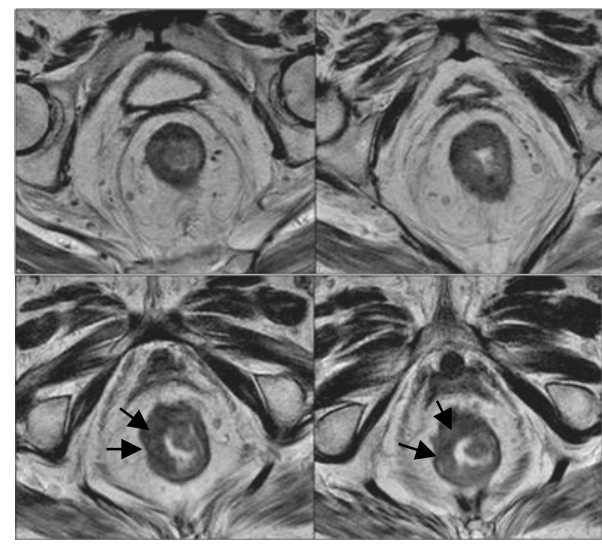

C

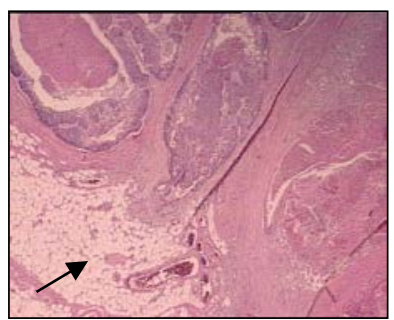

B

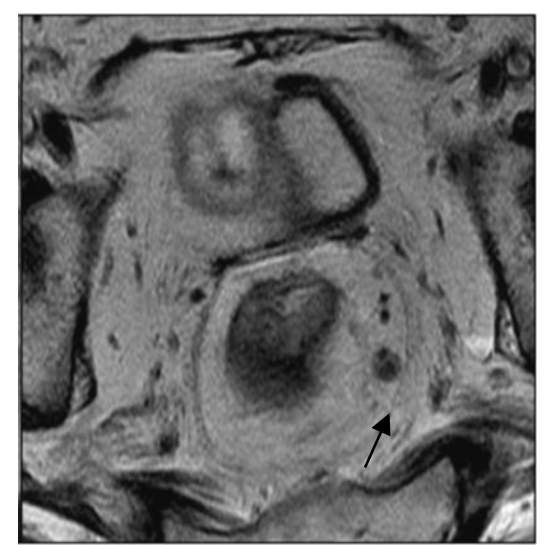

E
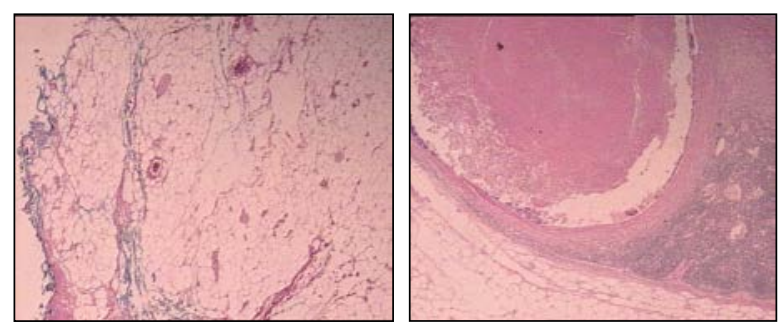

Figure 1. A 83 year-old female patient correctly staged by MRI (T3N1). (A) Consecutive T2weighted axial sections show rectal wall thickening, irregularities in the frontal wall and nodular extensions into the perirectal fat (arrows). (B) shows a metastatic lymph node with mixed signal intensity (arrow). Histopathology reveals (C) tumoral lesions bulging into the perirectal fat (arrow), (D) tumor-free CRM, and (E) a metastastatic lymph node with tumor necrosis and reactionary fibrotic areas; H\&E staining $\times 40$.

\section{A}

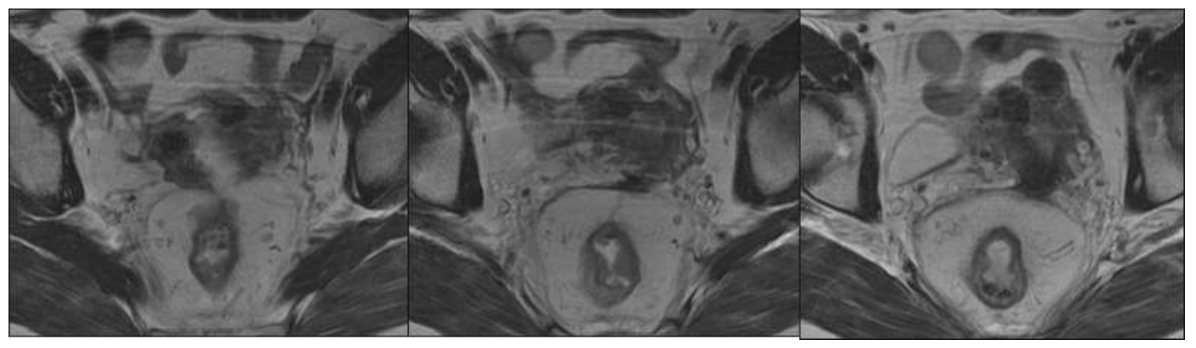

B

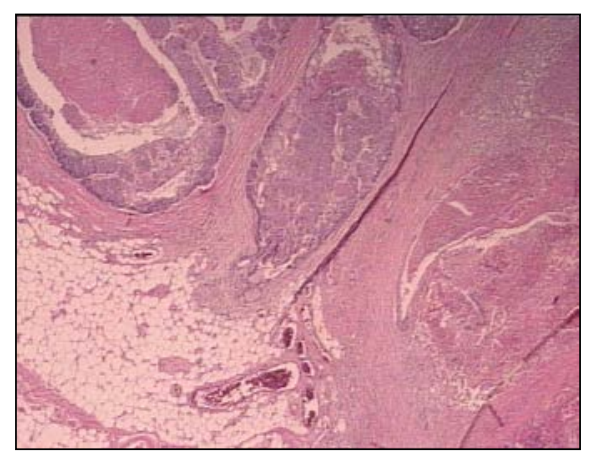

C

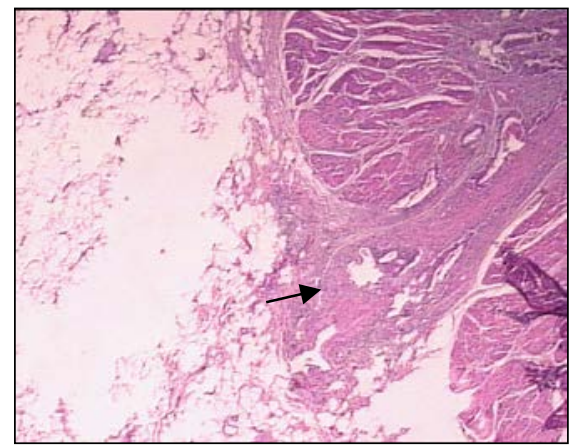

Figure 2. A 58 year-old female patient with pT3N0 tumor under-staged by MRI as T2N0. (A) Consecutive T2-weighted axial sections showing hypointense wall thickening with no apparent tumoral invasion into the perirectal fat. Microscopic examination revealed full thickness tumor involvement through the rectal wall (B), however perirectal fat invasion was focal (C); a group of tumoral glands reached perirectal fat in a fibrous band (arrow). H\&E staining $\times 40$.
In the standard MRI group, two pT1 tumors were over-staged as T2, one p'T2 tumor was over-staged as T3, one pT3 tumor was over-staged as T4 and five pT3 tumors were under-staged as T2. Over-staging of one pT2 and one pT3 tumor in the standard MRI group was thought to be related to a partial volume effect due to the absence of oblique axial sections perpendicular to the tumor. On the other hand, MRI correctly identified one stage T4 tumor with tumor invasion into the bladder. Of the pT3 tumors under-staged as T2, one had minimal perirectal infiltration and four had focal infiltration into serosa.

\section{Circumferential resection margin}

Table 2 presents positive CRM (distance from tumor to CRM $<1 \mathrm{~mm}$ ) as predicted by the thin-section and standard MRI protocols compared to histopathology. In the thin-section MRI group, 3 out of 22 patients had positive CRM, two of which were correctly identified by MRI. There was one false-positive and one falsenegative cases. Accuracy for predicting positive CRM was $67 \%$ showing good agreement with histopathology $(\kappa=0.61 ; p<0.05)$. Positive CRM could be detected with $67 \%(2 / 3)$ sensitivity, 95\% (18/19) specificity, 67\% (2/3) PPV, and 95\% (18/19) NPV.

Table 2. Positive CRM (distance from tumor to CRM $<1 \mathrm{~mm}$ ) prediction by MRI compared to histopathology in the thin-section $(n=22)$ and standard MRI $(n=15)$ groups.

\begin{tabular}{|c|c|c|}
\hline \multicolumn{3}{|c|}{$\begin{array}{c}\text { Thin-section MRI group ( }(\kappa=0.61, p<0.05) \\
\text { Histopathology }\end{array}$} \\
\hline MRI & CRM negative & CRM positive \\
\hline \multirow{3}{*}{$\begin{array}{l}\text { CRM } \\
\text { negative } \\
\text { CRM } \\
\text { positive } \\
\text { Total }\end{array}$} & 18 & 1 \\
\hline & 1 & 2 \\
\hline & 19 & 3 \\
\hline \multicolumn{3}{|c|}{$\begin{array}{r}\text { Standard MRI group ( } p>0.05) \\
\text { Histopathology }\end{array}$} \\
\hline MRI & CRM negative & CRM positive \\
\hline \multirow{3}{*}{$\begin{array}{l}\text { CRM } \\
\text { negative } \\
\text { CRM } \\
\text { positive } \\
\text { Total }\end{array}$} & 13 & 0 \\
\hline & 1 & 1 \\
\hline & 14 & 1 \\
\hline
\end{tabular}

In the standard MRI group there was only one patient with positive CRM, which was correctly identified by MRI. There was one false-positive case using the 
standard MRI protocol. Overall accuracy of the standard MRI protocol in predicting positive CRM was $50 \%$, with no statistically significant agreement with histopathological findings $(\mathrm{p}>0.05)$. In the standard MRI group, positive CRM could be detected with 100\% sensitivity (1/1), 93\% (13/14) specificity, 50\% (1/2) PPV and 100\% (13/13) NPV.

Histologically none of the patients had mesorectal fascia involvement without adjacent organ involvement and only one false-positive MRF involvement was predicted by thin-section MRI.

\section{N staging}

Table 3 presents nodal stage prediction by MRI in the thin-section and standard MRI groups compared with histology. In the thin-section MRI group accuracy of nodal stage prediction was $77 \%$ $(17 / 22)$ showing moderate agreement with histopathology $(\kappa=0.51 ; \mathrm{p}<0.05)$. For N0 stage, sensitivity was $93 \%$ (13/14), specificity 50\% (4/8), PPV $76 \%(13 / 17)$, and NPV 80\% (4/5). For N1 stage, sensitivity was $25 \%(1 / 4)$, specificity 94\% (17/18), PPV 50\% $(1 / 2)$, and NPV $85 \%(17 / 20)$. For N2 stage, sensitivity was $75 \% \quad(3 / 4)$, specificity $100 \%(18 / 18)$, PPV 100\% (3/3), and NPV 95\% (18/19). Overall, one patient was over-staged as N1 and four patients were under-staged as N0. Of the four under-staged patients, three patients had pN1 disease with either 1 , 2 or 3 positive-nodes on histopathology. The fourth patient had $\mathrm{pN} 2$ disease and a previous course of radiotherapy received one month before was thought to have influenced the MRI prediction.

In the standard MRI group, accuracy of nodal stage prediction was $87 \%$ $(13 / 15)$ showing good agreement with histopathology $(\kappa=0.75 ; \mathrm{p}<0.05)$. For N0 stage, sensitivity was $100 \%(9 / 9)$, specificity 83\% (5/6), PPV 90\% (9/10), and NPV $100 \%(5 / 5)$. For N1 stage, sensitivity was $63 \%(2 / 3)$, specificity $100 \%$ (12/12), PPV 100\% (2/2), and NPV 92\% (12/13). For N2 stage, sensitivity was $67 \%(2 / 3)$, specificity $92 \%$ (11/12), PPV 67\% (2/3), and
NPV 92\% (11/12). One patient with pN1 was over-staged as N2. One patient with $\mathrm{pN} 2$ was under-staged as N0, due to a history of previous radiotherapy.

Table 3. Nodal stage prediction by MRI compared to histopathology in the thin-section $(n=22)$ and standard MRI $(n=15)$ groups.

\begin{tabular}{|c|c|c|c|}
\hline \multicolumn{4}{|c|}{$\begin{array}{c}\text { Thin-section MRI group }(\kappa=0.51, p<0.05) \\
\text { Histopathology }\end{array}$} \\
\hline MRI & pN0 & pN1 & pN2 \\
\hline NO & 13 & 3 & 1 \\
\hline N1 & 1 & 1 & 0 \\
\hline N2 & 0 & 0 & 3 \\
\hline Total & 14 & 4 & 4 \\
\hline \multicolumn{4}{|c|}{$\begin{array}{c}\text { Standard MRI group ( }(\kappa=0.75, p<0.05) \\
\text { Histopathology }\end{array}$} \\
\hline MRI & pNO & pN1 & pN2 \\
\hline No & 9 & 0 & 1 \\
\hline N1 & 0 & 2 & 0 \\
\hline N2 & 0 & 1 & 2 \\
\hline Total & 9 & 3 & 3 \\
\hline
\end{tabular}

\section{Discussion}

In this study we investigated the accuracy of our standard phased-array MRI protocol and a thinner, $5 \mathrm{~mm}$ section oblique axial scan MRI protocol for predicting prognostic factors in rectal cancer patients. In our standard MRI group accuracy of T-stage and CRM predictions was low $(40 \%$ and $50 \%$, respectively), and there was no significant agreement with histopathology. In the thin-section MRI group accuracy of both predictions were improved, although T-stage accuracy was only fair (59\%), and CRM accuracy was modest (67\%). Nodal status predictions were better in both groups, being $87 \%$ accurate using the standard MRI protocol and $77 \%$ accurate using the thin-section MRI protocol.

$\mathrm{T}$ staging accuracy has improved with the introduction of high-resolution MRI. Moderate-high accuracy rates (74\%$100 \%)$ for $\mathrm{T}$ staging were reported using high spatial resolution thin-section MRI (11, 14-16). Despite significant improvement in the thin-section MRI group, our accuracy rates for $\mathrm{T}$ stage were on the lower side compared to the literature, mainly due to two factors. Firstly, 1.0 Tesla MRI unit did not permit the use of $3 \mathrm{~mm}$ sections which is used in most of the recently published studies. Secondly, a large number of patients with locally advanced tumors receiving preoperative chemoradiation therapy $(n=34)$ were excluded from the analysis.

The most frequent staging error using either MRI protocol was under-staging of borderline pT3 tumors. In the literature most T2/T3 staging errors are seen as over-staging of $\mathrm{pT} 2$ as opposed to under-staging of pT3 (14-17). This is because fibrotic spiculations can not be easily distinguished from extramural extensions containing tumor cells. In their study reporting $100 \%$ accuracy in predicting $\mathrm{T}$ stage using high resolution MRI, Brown et al. (11), claimed that fine spiculations by themselves should not be considered tumoral invasion unless they are broadbased nodular extensions contiguous with the tumor. We used the criteria of Brown et al. (11), in deciding extramural invasions, but the lower resolution in our scans may have unfavorable effect on our MRI results for staging (Figure 1). However, we believe that clinical decision making did not suffer as a consequence of understaging of borderline p'T3 tumors, since all of our misdiagnosed patients had clear CRM and did not need additional therapy.

Three patients in our study group had pT1 tumor and all three were over-staged as T2 in the MRI analysis. Identifying tumors without mural penetration is important, as organ-sparing local excision could be curative in some patients. Unfortunately, preoperative staging of very early or early stage tumors continues to be a challenge. Endorectal ultrasound is believed to be more sensitive in identifying early tumors, but it is highly operator dependent and large studies show that staging accuracy is not as high as previously reported $(18,19)$. The only advantage of ERUS over MRI is the possibility of assessing T1 tumors that could be managed by transanal endoscopic microsurgery (20).

CRM involvement is an important predictor of local recurrence $(21,22)$. Patients likely to have a positive CRM can benefit from preoperative radiotherapy or chemoradiotherapy to reduce the risk 
of local recurrence. Studies show that MRI is an effective tool for accurately detecting the CRM status $(17,23,24)$. In our study, the number of patients with positive CRM was low, possibly due to exclusion of all patients allocated for neoadjuvant therapy. Despite the small number of patients, prediction of CRM status was improved with thinsection MRI compared to standard MRI.

Although an important predictor of disease recurrence and overall survival, nodal status is still difficult to assess in most cases. Studies show that nodal size is not a reliable indicator of metastasis, since small nodes may sometimes be metastatic (25). Irregular borders (spiculated, indistinct borders) and mottled heterogenous signal intensity are better prognostic factors than the size of the lymph node $(12,26)$. We used these morphological criteria in our study and found good correlation with histology in both groups. In contrast to above mentioned studies which classified nodal status as node positive

\section{REFERENCES}

1 Heald RJ, Ryall RD. Recurrence and survival after total mesorectal excision for rectal cancer. Lancet 1986;1:1479-1482.

2 Sauer R, Becker H, Hohenberger W, et al. Preoperative versus postoperative chemoradiotherapy for rectal cancer. N Engl J Med 2004;351:1731-1740.

3 Sebag-Montefiore D, Stephens RJ, Steele $\mathrm{R}$, et al. Preoperative radiotherapy versus selective postoperative chemoradiotherapy in patients with rectal cancer (MRC CR07 and NCIC-CTG C016): a multicentre, randomised trial. Lancet 2009;373:811-820.

4 Zengel B, Uslu A, Adibelli Z, et al. Adjuvant versus neoadjuvant chemoradiotherapy in distal rectal cancer: Comparison of two decades in a single center. Ulus Cerrahi Derg 2015;31:218-223.

5 Algebally AM, Mohey N, Szmigielski W, et al. The Value of High-Resolution Technique in Patients with Rectal Carcinoma: Pre-Operative Assessment of Mesorectal Fascia Involvement, Circumferential Resection Margin and Local Staging. Pol J Radiol 2015;80:115121. or negative, we classified nodal disease according to TNM, in N0, N1 and N2 subgroups and obtained $77 \%$ and $87 \%$ accuracy rates using the thin-section and standard MRI protocols, respectively.

Although T1-weighted gadoliniumenhanced sequences were obtained in each patient as part of the protocol, they did not appear to have better image quality and ultimately only T2-weighted scans were used in the analysis. In this study we did not attempt to compare accuracy of preoperative staging with and without IV gadolinium-chelate administration. However, other studies evaluating the diagnostic efficacy of contrast-enhanced sequences in rectal cancer imaging did not show improved accuracy in T stage, CRM or nodal stage predictions (27-29). Since, administration of IV contrast material increases scanning time considerably, we think it can be omitted altogether to lessen examination time and also the patient discomfort and allow more efficient use of the MRI unit.
There are some limitations of this study. The scans were analysed by a single radiologist, thus interobserver agreement could not be investigated. Although this was a prospective study, patients could not be randomized, since the original study design aimed to investigate accuracy of the standard MRI protocol and thin-section MRI techniques were adopted half-way through the study. In addition, a large proportion of the intended study population had to be excluded since neoadjuvant therapy was initiated in most patients suspected of having locally advanced disease.

In conclusion, our study showed that even with a 1.0 Tesla MRI system tumor stage and circumferential resection margin predictions can be improved considerably by adopting thin-section MRI techniques. However, a higher field magnet system allowing $3 \mathrm{~mm}$ section thickness would be needed to achieve the level of accuracy reported in the literature.
6 Balyasnikova S, Brown G. Imaging Advences in Colorectal Cancer. Curr Colorectal Cancer Rep 2016;12:162-169.

7 Gregory dePrisco. MRI Local Staging and Restaging in Rectal Cancer. Clin Colon Rectal Surg 2015;28:194-200.

8 Brown G, Daniels IR, Richardson C, et al. Techniques and trouble-shooting in high spatial resolution thin slice MRI for rectal cancer. Br J Radiol 2005;78:245-251.

9 Smith N, Brown G. Preoperative staging of rectal cancer. Acta Oncol 2008;47:20-31.

10 International Union Against Cancer (IUCC). TNM Classification of Malignant Tumors, 7th ed. Sobin LHG, Gospodarowicz M.K., Wittekind C, editors. Oxford: Wiley-Blackwell; 2009.

11 Brown G, Richards CJ, Newcombe RG, et al. Rectal carcinoma: thin-section MR imaging for staging in 28 patients. Radiology 1999;211:215-222.

12 Brown G, Richards CJ, Bourne MW, et al. Morphologic predictors of lymph node status in rectal cancer with use of highspatial-resolution MR imaging with histopathologic comparison. Radiology 2003;227:371-377.
13 Quirke P, Durdey P, Dixon MF, Williams NS. Local recurrence of rectal adenocarcinoma due to inadequate surgical resection. Histopathological study of lateral tumour spread and surgical excision. Lancet 1986;2:996-999.

14 Akasu T, Iinuma G, Fujita T, et al. Thinsection MRI with a phased-array coil for preoperative evaluation of pelvic anatomy and tumor extent in patients with rectal cancer. AJR Am J Roentgenol 2005; 184:531-538.

15 Brown G, Radcliffe AG, Newcombe RG, et al. Preoperative assessment of prognostic factors in rectal cancer using high-resolution magnetic resonance imaging. Br J Surg 2003;90:355-364.

16 Poon FW, McDonald A, Anderson JH, et al. Accuracy of thin section magnetic resonance using phased-array pelvic coil in predicting the T-staging of rectal cancer. Eur J Radiol 2005;53:256-262.

17 Beets-Tan RG, Beets GL, Vliegen RF, et al. Accuracy of magnetic resonance imaging in prediction of tumour-free resection margin in rectal cancer surgery. Lancet 2001;357:497-504. 
18 Garcia-Aguilar J, Pollack J, Lee SH, et al. Accuracy of endorectal ultrasonography in preoperative staging of rectal tumors. Dis Colon Rectum 2002;45:10-15.

19 Marusch F, Koch A, Schmidt U, et al. Routine use of transrectal ultrasound in rectal carcinoma: results of a prospective multicenter study. Endoscopy 2002; 34:385-390.

20 Burdan F, Sudol-Szopinska I, Staroslawska E, et al. Magnetic resonance imaging and endorectal ultrasound for diagnosis of rectal lesions. Eur J Med Res 2015;20:4 .

21 Birbeck KF, Macklin CP, Tiffin NJ, et al. Rates of circumferential resection margin involvement vary between surgeons and predict outcomes in rectal cancer surgery. Ann Surg 2002;235:449-457.
22 Wibe A, Rendedal PR, Svensson E, et al. Prognostic significance of the circumferential resection margin following total mesorectal excision for rectal cancer. Br J Surg 2002;89:327-334.

23 Mercury Study Group. "Diagnostic accuracy of preoperative magnetic resonance imaging in predicting curative resection of rectal cancer: prospective observational study." BMJ 2006;333:779.

24 Purkayastha S, Tekkis PP, Athanasiou T, et al. Diagnostic precision of magnetic resonance imaging for preoperative prediction of the circumferential margin involvement in patients with rectal cancer. Colorectal Dis 2007;9:402-411.

25 Ucar A, Obuz B, Sokmen S, et al. Efficacy of High Resolution Magnetic Resonance Imaging in Preoperative Local Staging of Rectal Cancer. Mol Imaging Radionucl Ther 2012;22:42-48.
26 Kim JH, Beets GL, Kim MJ, et al. Highresolution MR imaging for nodal staging in rectal cancer: are there any criteria in addition to the size? Eur J Radiol 2004;52:78-83.

27 Vliegen RF, Beets GL, von Meyenfeldt MF, et al. Rectal cancer: MR imaging in local staging--is gadolinium-based contrast material helpful? Radiology 2005; 234:179-188.

28 Jao SY, Yang BY, Weng $\mathrm{HH}$, et al. Evaluation of gadolinium-enhanced T1weighted magnetic resonance imaging in the preoperative assessment of local staging in rectal cancer. Colorectal Dis 2010;12:1139-1148.

29 Gollub MJ, Lakhman Y, McGinty K, et al. Does Gadolinium-Based Contrast Material Improve Diagnostic Accuracy of Local Invasion in Rectal Cancer MRI? A Multireader Study. AJR Am J Roentgenol 2015;204:160-167. 
